\title{
The landscape-beyond the dichotomy of nature and culture
}

\section{Iwona Lorenc}

(University of Warsaw; Institute of Philosophy)

\section{Beyond the dichotomy of nature and culture}

Since the anti-positivist protest, one of the crucial tasks of the humanities is the ceaseless deconstruction of the divide between culture and nature. After all, this conceptual distinction had been an inalienable element of the game of concepts played by metaphysically anchored aesthetics and, both in the positive and negative sense, it lay at the historical foundations from which the theoretical awareness of the cultural sciences emerged. The new senses of concepts which constitute that dichotomy are employed in the description of new, emergent phenomena of culture and civilization. The certainty surrounding the dichotomy is being challenged.

I concur with those who, like Anna Pałubicka (1997, 91-108), hold that modernity's characteristic conviction of the basic nature of the culture-nature dichotomy is nothing more than the upshot of a particular mode of thinking which people have been inducted into through culture, one expressed via philosophical reflection (though not exclusively). Those inculturation processes are founded on specific cultural conceptions that people accept. The responsibility for the reflective acceptance of the nature-culture dichotomy should be attributed both to the rationalism of the Cartesian tradition and the Rousseauian-Romantic response.

Today it is obvious that drawing on studies into processes in which both types of reality become superimposed on one another is much more theoretically fruitful; processes taking place in the domains of science and art alike, as well as in new technologies, include those which possess civilizational significance and those which determine new forms of artistic communication. The processes in question are observed from two standpoints: the denaturalization of nature and naturalization of culture, whereby so-called "second nature" is brought forth, while studies of landscape represent one of the major areas of reflection concerning the mutual superimposition of both processes. Accounting for that dual-aspect process in which 
our modernity (with its post-modern modification) partakes, requires a different language from that which more or less indirectly subscribes to the old opposition of nature and culture.

To conclude this perhaps all-too-obvious train of thought, which was nevertheless required for the purposes of clarification, one should underline the role of landscape studies as a category requiring a reformation of the semantic field of "sciences of culture" (including philosophy of culture), which undoubtedly has been taking place since the 1896 promulgation of Heinrich Rickert's Kulturwissenschaft und Naturwissenschaft. The disciplines developing today in the domains distinguished by Rickert define the focus areas of their inquiry through their departure from the classic culture-nature opposition in favour of a perspective which abolishes that divide and reveals new contradictory relations instead-relations such as "culturecivilization" (an issue addressed e.g. by Husserl, Jaspers, Heidegger, Horkheimer, Adorno, and Morawski in Poland, among others).

If the notion of culture were to be construed as Morawski does, namely as the "entirety of social life considered in terms of values, norms, ideals and directives which influence the convictions and the manner in which individuals act" (Morawski 1999, 278), then this entirety would most likely contain a phenomenon like the experience of landscape, which represents a matter of interest for aesthetics as well and makes it possible to establish a shared area of research for several disciplines of the humanities (which, apart from philosophical aesthetics and philosophy as such, would involve history of art, philosophical anthropology, sociology, psychology, philosophy of culture or politics). This joint area emerged precisely as a result of the disruption (erasure, invalidation) of the traditional opposition "nature-culture", at the juncture where the scopes of multiple disciplines intersect.

\section{Issues of landscape and selected modern tendencies in culture}

At this point, I would highlight two problem areas I find interesting. The first encompasses issues relating to aestheticization, a phenomenon discussed by e.g. Welsch as a modern cultural strategy (along with anaestheticization as a defensive response to that strategy), one which subordinates all domains of reality, including nature and economy, to aesthetic criteria. The experience of landscape is, in my view, ideally suited for the observation of aestheticization tendencies, which are additionally enhanced by the processes - to use Giddens's language-of uprooting the modern human from traditional, spatio-temporal modes of establishing a setting for their experience. As emphasized by Mitchell (1994), Augé (1997) or Belting (2007), who drew on the latter, contemporary "land-images" (in the form displayed at and around travel agencies) no longer occupy a specific location in space-time, but 
function as u-topian, culturally constructed never-places to which one flees from the oppressive aspects of the world. Becoming tokens in the culturally (as well as economically and politically) generalized process of exchange, they do deserve the name of travelling images. This makes them an even more compelling object of inquiry for contemporary humanities, which have to confront the fluid, volatile nature of their subject matter (Bal 2002).

The desire to be rooted yet again in a "potent" experience of reality leads to a situation where-as Belting observes-"in non-places we dream of real places, just as our ancestors dreamed the reverse" (2014). However, this recycled, projected "reality" of an aestheticized landscape turns out to be "a plague of fantasy" (as I would agree with Žižek that it is) - as the promise of reality can never be fulfilled. The serene and restful landscape of the field of Provence seen from the car or desert watched from the back of a camel hired by the hour is as much illusory contact with "reality" as the modern cultural phantasm of the conflicting structure "nature-culture" on which it is based.

The second area of interest covers questions relating to the cultural and aesthetic functioning of so-called "second nature", associated among other things with the reorganization of the sphere of aisthesis (and comprising the critique of ocular-centrism pursued by e.g. Heidegger, Wittgenstein, Foucault, Derrida) or research on the impact of the media on contemporary perceptual experience. Naturally, there is a link between the two areas of interest I have distinguished. Transformations within aisthesis are connected with the fundamental shift of cultural patterns and requirements, so these problems as well as issues of the derealization of reality or revisions of values in everyday experience should become the object of interdisciplinary scrutiny within the humanities.

As for the aforementioned topics, I am particularly interested in the possibility of exploiting the hermeneutic potential of a phenomenology of the senses in studies on broadly understood aesthetic experience. I believe it to be a promising approach if applied in studies concerned with the experience of landscape. It is all the more promising in that it ensures an alternative path for research conducted as part of visual culture studies which, as Mitchell pointedly observes, identified the key importance of the category of visuality as coined by Foster-the conviction that the "human is a seeing being" (Mitchell 2013, 20). From the standpoint of visuality studies, landscape is a "category pertaining to the environment of human life, reflecting the mode of understanding or capturing that environment, but at the same time a category produced visually, not only through the action of language, but above all by means of the eye" (Ibidem).

In comparison with this approach, the phenomenological-hermeneutical take on the category of aisthesis considerably extends the experience of landscape to include other dimension of sensation, thus gravitating towards the poly-sensory character of such an experience. This agrees with my method of hermeneutically 
oriented phenomenology. If I were to express my approach in the most general terms, I would draw primarily on Heidegger, and subsequently Merleau-Ponty (read more profoundly than his rhetoric of visibility, which raises at least the suspicion of ocularcentrism), as well as French post-phenomenology (Depraz, Escoubas, Henry, Richir) and new German phenomenology (Schmitz, Waldenfels).

One of the vital elements here is the hermeneutic opening in Heideggerian phenomenology which, inspired by certain possibilities found in Husserl, became a powerful stimulus for contemporary phenomenologists. The point is to attain a phenomenology which would not limit the scope of research to the noetic-noematic structure, nor would be solely a phenomenology of passive recipience, whose source is in its nature unfathomable and untouched by meaning. Admittedly, this does account for our receptive sensibility to what eludes codified cognitive structure, to the impact and pre-notional communication emanating from the world in which we are immersed. However, it is always that immersion in the world, its actual dimension-as early Heidegger would have put it-which harbours the traits of comprehension characterized by pre-verbal structurations that generate meaning. Only from those (which Husserl had observed) do linguistic formulations arise.

\section{The significance of the Heideggerian and phenomenological viewpoints for the studies of landscape}

Before I outline at least some of the possibilities that the above perspective of contemporary phenomenology offers to studies of landscape, I would like to draw attention to the potency of Heideggerian impulses which provide and may provide the motive force for such studies.

When writing about the actual dimensions of human existence, Heidegger attributed its dynamics to "being oriented" towards what is open (ins Offene). In his interpretation of that aspect of human existence in Heidegger, Peter Sloterdijk aptly separates it from interpretive schemes of transcendental and anthropocentric occlusion. We share the penchant for the openness of being with other living beings: “...virtually all organisms or integrities transcend into the first-level spaces of surprise and conflict that are assigned to them as their respective environments (even plants do this, and animals all the more so), only very few-only humans, as far as we know-achieve the second level of transcendent movement. Through this, the environment is de-restricted to become the world as an integral whole of manifest and latent elements." (Sloterdijk 2014, 14).

There is a strong and justified temptation to follow that path in the studies of landscape. It would be an area of research into the emerging movement of transcendence to which all living organisms are entitled. This movement-culturally "tamed"retains properties shared by the entire natural world and simultaneously-via 
representational-visual means of "taming" the natural-elevates them to a higher mode of being that is proper to humans.

"That second step", Sloterdijk writes, "is the work of language ["of the symbolic," let us add.-I. L. ]. This not only builds the ,house of being' [...]; it is also the vehicle for the tendencies to run away from that house with which, by means of its inner surpluses, humans move towards the open. It need hardly be explained why the oldest parasite in the world, the world above, only appearswith the second transcendence" (Ibidem).

Heidegger's rhetoric of openness is complemented and balanced by the rhetoric of habitation. Landscape would constitute a category in the boundary area between them. The experience of landscape in its existential-fundamental modality (in Heideggerian ontological-fundamental sense) would simultaneously be an experience of being "within" and being "without".

When discussing the spatiality of being-in-the-world of Dasein in section 23 of Being and Time, Heidegger uses a term he considers crucial, namely Ent-fernung [dis-tancing]. Our being among things, being "in" the world, our taking a position with respect to it is possible only at a distance, but the vital sense of that distance from being is in fact in the annihilation of remoteness, and thus-paradoxicallybringing it near. I am comprehendingly "in" the world (approach it) only when I discover the "remoteness" (Entferntheit) of being. To Heidegger, the dis-tancing is an existential which enables the practical, theoretical or artistic realization of relationships between myself and things in the world.

By virtue of such dis-tancing, the image (especially the land-image), brings the human and their surroundings closer, integrates them; at the same time, it imposes a certain framework (be it cultural, aesthetic, formal etc.) on those surroundings and our relationship to them. Consequently, we can see and understand (also in the sense of comprehending experience) our relationship with our surroundings and with ourselves only when de-distanced from the world and ourselves-only through the mode of our spatial (in the Heideggerian sense) being in the world. In this context, a number of categories become substantially significant for the studies of landscape: the corporeality of the land-image (i.e. its medium, its "flesh", which means the presence of both the human body and the world where it abides, both "delegated" into the medium), as well as transitiveness of the image (i.e. its capacity for circulating between the visible and the invisible). In short, image is something which through mediated and substitutive dis-tancing brings our own experience of spatial being in the world closer to us. In the approach suggested here, the comprehension of land-image is defined by the need to understand the human and human surroundings. Land-image, as well as image in general, arises from the processes of symbolization of "lived references" of the human being, including their experience of time and space. 
In this respect, Merleau-Ponty offers inspiration as he underlines the significance of the corporeal dimension of both imaged human experience, as well as the corporeal dimension of the image itself as a "symbolic body". Phenomenological and anthropological viewpoints (the latter is yet to be addressed) support and complement each other. Just like Merleau-Ponty, Belting was far from instrumentalising the medium of image. On the contrary, he speaks about the "physics of image which endows an autonomous significance to image media" (Belting 2007, 297), for which the "what" and the "how" of an image are both sides of the same coin.

The perceived and the inner images witness a process of exchange and reciprocal dependence, and this observation of Belting can readily be applied to the experience of landscape. Leaving Belting aside and anticipating certain interpretive possibilities offered by categories suggested by Merleau-Ponty, one could speak here of the relation of inter-corporeality as of an exchange taking place between the "body of image" and "our body, which for its part constitutes a natural medium" (Belting 207, 305), an intercorporeal exchange between the human and the world which is effected through the "body of image". It should also be noted that this is an exchange between the visible and the invisible. In this approach, deriving from the tenets of Belting's anthropology of image, land-image (as a particular instance of image) becomes a determined mode of transmitting presence, one proper to human being in the world.

This viewpoint is particularly rewarding when coupled with the Merleau-Ponty's late concept of inter-corporeality, in which two perspectives are combined: the phenomenology of perception, specifically modified with respect to his earlier propositions, and a unique hermeneutics of culture.

As Renaud Barbaras puts it, in late Merleau-Ponty "that which leads from Being to visibility [...] is the intrinsic visibility of Being which harbours the possibility of subjectivity: the appearance of the viewer is synonymous with the attainment of visibility in a form with a specified semblance. Let it be noted that this gesture brings Merleau-Ponty singularly close to Aristotle who, disregarding the divergence of nature and consciousness, ignoring that which is within and the phenomenon, recognizes thus the precession of vision, in the form of a force, within the visible. It is at any rate that irreducible and autonomous visibility which MerleauPonty calls chair, thinking obviously about the body itself, where the sensing and the sensed are neither fully identical nor utterly distinct" $(1998,26)$. Merleau-Ponty can, therefore, in The Visible and the Invisible, characterize perceptual corporeal experience in terms of "excess", the surpassing of oneself on the way to meaning. The experience, as an openness to the transcendence of being, defies the identity thesis, since it means experiencing identity and non-identity of one's own object at once. In late Merleau-Ponty, becoming is the mode of being of beings. Being is its own reification, a ceaseless attainment of visibility, whereas the invisible is not beyond the range of visibility, but a component of the visible understood as 
a potentiality, a moment of its motion of actualization. This motion is the becoming of the phenomenon, an explosion of the visible.

The experience of being is inextricably linked to the experience of non-identity and being: the fullness of what is one's own in perceived being requires negativity to participate in that perception; the visible subsumes the dimension of the invisible. Being is endowed with irreducible depth, therefore questions about being are a consent to its opacity, to our immersion in it—which is why it perpetually exceeds us. So, participant questioning about being is a discovery of its transcendence. The experience of landscape is one of the modes of such comprehending, an interrogative opening to what surpasses us in that experience.

Questioning about being and its perception take place within the world: my body is what sees; the seeing one is simultaneously visible, it is inscribed in the world which becomes visible precisely in virtue of this inscription, and for that very reason it does not constitute identity-with-oneself-it is not a being in itself, but contains its own negation. Given that percipi represents an inseparable moment, its complete totalization, the attainment of its full meaning is impossible.

Thus Merleau-Ponty sees an affinity between the category of meaning and the experience of opacity, the fragmentry nature of the experienced world-issuing precisely from the corporeal nature of that experience. The meaning of being in the world, reified in the experience of living corporeality is an indestructible tissue, a conjunction of moments which can no longer be polarized into the opposition "in oneself"- "for oneself". So for Merleau-Ponty body is not embodied consciousness (subjectivity). By being in the world, consciousness eludes itself; even if it happens to touch itself, then that is only fragmentarily, peripherally. The intentionality of the body is its motoricity-an ecstasy, an externality with respect to itself, an entrance into the world as opposed to pure immanence.

Own body reveals the meaning of what Merleau-Ponty calls the "living tissue of being", the flesh [chair]: a reciprocal dependence within which the visible-on the one hand-emerges along with the seeing body, while on the other hand the body's capacity for seeing is subordinated to the nascent visibility of the world (Barbaras 1998, 134). So, Merleau-Ponty notices the essential, ontological continuity between the body and the world. It is the source of a singular paradox: the contact of the body with itself is only feasible only as being distanced from itself, only as own absence and the presence of the world.

Land-image (land-scape) as the space-time of my surroundings experienced through imagery enables that interplay of continuality and distance between my body and the body of the surroundings. After all, my body is not given to me as an assemblage of ready-made facilities; the thinking of my body, i.e. its functions, its position with respect to things, its temporality and spatiality, are established in relationships with the things which surround it, as well in self-referential interaction of the body with itself. 


\section{From phenomenology to philosophical anthropology}

In the spirit of Merleau-Ponty's postulates as outlined above, and following the path traced by Belting, the phenomenon of inter-corporeality may be deemed a vital dimension of our being in the world, a tissue of existential human experience. The production of images and their internalization is an important way of coping with the problems engendered by the spatial nature of our being in the world (in the sense of spatiality referred to in connection with Heidegger), with experiencing its temporally evanescent presence, as well as with determining our own position among the "things of this world".

The existential, aesthetic, sensorial, corporeal and intercorporeal status of these arrangements (that "mute, pre-linguistic logos", as Merleau-Ponty would put it) becomes a task for the new hermeneutics of the sense and for the phenomenology which remains open to hermeneutics thus construed. In a certain way, somewhat altered by Heidegger, we continue along the lines of Husserl's genetic phenomenology and accomplish - going further than he could have-one of his principal goals: to pinpoint and philosophically capture the motion of the phenomenalization of the world in which we-living, feeling, acting and comprehending people-are immersed-i.e. the conditions and processes by virtue of which the world reveals itself to us as a phenomenon.

As regards studies on the experience of nature, including landscape, the tasks of phenomenology thus-conceived dovetail perfectly with the anthropological perspective. I have already remarked on the correspondence of approaches devised by Merleau-Ponty and Belting. I will attempt to show much the same by drawing on the conceptions of Gernot Böhme. In doing so, I will rely on latter's Filozofia $i$ estetyka przyrody (2002), published by Oficyna Naukowa (in their Terminus series), which is based on two works by the Böhme, namely Für eine oekologische Naturaesthetik (Böhme 1989) and Naturliche Natur. Über Natur im Zeitalter ihrer technischen Reproduzierbarkeit (Böhme 1992).

I choose to cite Böhme in view of the fact that his idea illustrates the indivisibility of anthropological-phenomenological studies (where the hermeneutic potential of phenomenology is taken for granted) and philosophical-critical inquiry into aesthetic experience in the context of issues of modernity. I am particularly interested in instances where these paths of research intersect, with landscape a category situated at that very intersection.

Böhme's aesthetics of nature focuses on "reflection on the phenomena which accompany human presence in their natural surroundings" (as encapsulated by Stanisław Czerniak in the preface to Böhme's, aforementioned, book). That presence constitutes a broadly understood experience and cannot be reduced to merely receptive sensations issuing from the natural world. Furthermore, the human, situated relative to and within nature, is a co-creator of the object and conditions of 
that experience. At the same time, according to Böhme, the experience of nature goes hand in hand with the emanation of "atmospheres"-a way of opening up to the objective emotional qualities of nature, which Böhme terms "characters". That which may be referred to as the "moods of landscape" is not associated with the subjective emotional states of the perceiving subject, but constitutes their inseparable, objective trait.

Putting it very briefly indeed, Böhme's project presupposes that aesthetic contemplation does not occur at a distance with respect to its object; it is a symbiosis of corporeality and the objective "characters" of nature. If that aspect of his conception were to be considered while disregarding the actual or direct influence and inspiration of historical-philosophical thought, it could be aligned with solutions advanced in contemporary phenomenology and anthropologically-oriented phenomenology, solutions which are particularly involved with categories of corporeality, own body or lived corporeality-the flesh (chair). The body is the locus where the ontological becomes interwoven with the cognitive and the aesthetic.

Both in the latter tradition and in Böhme-who draws his inspiration from the Frankfurt school-one readily notices the ease of transitions between those three perspectives, their mutual, compensatory substitutability. Aesthetics rises to the rank of reflection on the source relation linking the human and the natural world, a bond established in the realm of aisthesis, which is then translated into artistic work which draws on that source and attests to it. However, just like the entire culture, it is exposed to the threat of alienation, fallacious designations and artificial dichotomies. So, aesthetics focusing on sources is also a critique, particularly of culture and art in their alienated forms.

In the light of the above arguments, the aesthetic experience of the beauty of landscape is in no way opposed to nature, nor is it anything that has been "added" to nature-it is nature's way of existence. The capacity for expression and making itself perceptible are properties of nature, which includes the nature of human corporeality as well. They require the experience of beauty in order for the human and the natural to penetrate and permeate each other.

Being thus in line with the philosophical-aesthetic rehabilitation of aisthesis (corporeality, sensuality, liveliness), Böhme seems to share the compensatory-emancipatory aspirations of certain representatives of contemporary philosophy and philosophical anthropology. As an example, one could cite the Romantic-Marquardian current on the one hand, and Horkheimer, Adorno, Benjamin and Marcuse on the other. Hence the matter in question (let us repeat) is a broadly understood context of contemporary rehabilitation of the sphere of aisthesis, where-following in the footsteps of Nietzsche-the plea to restore the lost liveliness and Dionysian character to culture, despite or through its Apollonian element, became interwoven with post-Kantian attempts to reinvigorate or substitute "enervated reason" (Welsch, Marquard), to augment its forces by recourse to the aesthetic power of reconciling 
the sensual with the conceptual, the individual with the universal. However, these mechanisms do not amount to a renouncement of what is cultural in favour of a return to nature. Their element is one of cultural acts of critical self-awareness, working to develop a new anthropological identity; not against nature, but in amicable concord with it.

The educational dimension of a perspective thus formulated is very clear: the perception of landscape may be a school of phenomenological-hermeneutic sensibility, one which would expand the scope of our experiences and self-awareness. A sensibility which is at once aesthetic and ethical.

This approach is conditional, however, on there being an education that includes critical reflection on the condition of the modern human and on the limitations of modern models of humanity aiming at rule over nature and its instrumental treatment.

\section{Bibliography:}

Augé, Marc. 1997. L'Impossible voyage. Le tourisme et ses images. Paris: Rivages.

Bal, Mieke. 2002. Travelling Concepts in the Humanities: A Rough Guide. Toronto: University of Toronto Press

Barbaras, Renaud. 1998. Le tournant de I'experience. Recherches sur la philosophie de Merleau-Ponty

Paris: Librairie Philosophique J.Vrin.

Belting, Hans. 2007. Antropologia obrazu: szkice do nauki o obrazie, trans. Mariusz Bryl. Kraków:

Universitas [English translation: Belting, Hans. 2014. An Anthropology of Images. Picture, Medium,

Body. New Jersey: Princeton University Press].

Böhme, Gernot. 1989. Für eine oekologische Naturaesthetik. Berlin: Suhrkamp Verlag.

Böhme, Gernot. 1992. Naturliche Natur. Über Natur im Zeitalter ihrer technischen Reproduzierbarkeit.

Berlin: Suhrkamp Verlag.

Böhme, Gernot. 2002. Filozofia i estetyka przyrody [Philosophy and the Aesthetics of Nature]. Warsaw:

Oficyna Naukowa.

Mitchell, W. J. Thomas. 1994. Landscape and Power. Chicago: University of Chicago Press.

Mitchell, W. J. Thomas. 2013. Czego chcą obrazy? Warsaw: Narodowy Centrum Kultury. [English original:

Mitchell, W. J. Thomas. 2004. What Do Pictures Want? Chicago: University of Chicago Press]

Morawski, Stefan. 1999. Niewdzięczne rysowanie mapy: O postmodernie(izmie) i kryzysie kultury. [The

Thankless Drawing of Maps: On Postmodern(ism) and the Crisis of Culture]. Toruń: Uniwersytet Mikołaja Kopernika.

Pałubicka, Anna. 1997. "Racjonalizm i empiryzm w interpretacji kulturoznawczej" ["Rationalism and empiricism as interpreted by cultural studies"]. In Pałubicka, Anna, ed. 1997. Kulturowe konteksty idei filozoficznych, Poznań: Wyd. Naukowe IF UAM.

Sloterdijk, Peter. 2014. Musisz życie swe odmienić. O antropotechnice, trans. by Jarosław Janiszewski. Warszawa: PWN. [English translation: Sloterdijk, Peter. 2013. You Must Change Your Life, trans. by Wieland Hoban. Malden, MA: Polity Press]. 